\title{
Iran's Nuclear Program: U.S. Options After the Elections
}

\section{Matthew Rhodes *}

Iran's growing nuclear capability is emerging as the number one issue for the Bush Administration in its second term. For the past three years, the dominant focus on Iraq, in the words of former Secretary of State Colin Powell, "sucked the oxygen" from other security issues. Now, however, it is increasingly Iran that stands center-stage in defining the uses and limits of the strategy of preemption, the agenda for the broader Middle East, and the future of America's relations with Europe.

\section{Iran's Nuclear Program}

Iran's first steps toward nuclear capability date back to the time of the Shah. These efforts have continued under the post-revolution Islamic Republic. As a signatory of the Non-Proliferation Treaty, made permanent in 1995, Iran has a right to develop nuclear technology for peaceful, civilian purposes, but forswears the development of weaponized applications.

Iran's leadership continues to insist it adheres to these conditions. However, the general temptations nuclear weapons offer in terms of perceived prestige and security, together with Iran's pattern of deception and concealment of important elements of its program, have raised doubts about its true intentions. For example, Iran failed to disclose the existence of a large uranium enrichment facility at Natanz or a plutonium separation plant at Arak to the International Atomic Energy Agency until after a tip from an exile group in 2002. A series of subsequent IAEA reports has highlighted additional discoveries, such as advanced centrifuge designs from Pakistan, and criticized Iran's halting cooperation with inspectors.

Questions of intent aside, estimates of the timeframe under which Iran would achieve the capability to produce usable nuclear weapons vary from as little as a year according to some U.S. sources to five to six years, according to intelligence agencies in Europe. ${ }^{1}$ Israel reportedly expects this threshold to be breached in just two years, by 2007.

\section{Learn to Love It}

Though little discussed publicly, one possible reaction would be to view a nuclear-capable Iran as a matter of little concern, or even as something desirable. After all, despite its parallel missile program, an Iran with a handful of crude nuclear devices would for some decades lack any credible means of delivery against the U.S. home-

* Dr. Matthew Rhodes, Professor of National Security Studies, George C. Marshall European Center for Security Studies. The opinions expressed in this article are those of the author alone.

1 Marc Champion and Carla Ann Robbins, "EU Believes Iran is 5 to 6 Years from Atom Bomb," Wall Street Journal, 10 November 2004. 
land. More fundamentally, such an Iran would still be subject to the logic of deterrence and threat of retaliation by not only America's nuclear arsenal, but its overwhelmingly superior conventional forces as well. Meanwhile, the defensive reassurance of nuclear weapons could prove a stabilizing, moderating influence on Iran's relations $v i s-\grave{a}$-vis its regional rivals.

Two sets of concerns run counter to this reasoning. The first focuses on some specific characteristics of Iran. The country's recent history as a tribune of wider Islamic revolution and as a sponsor for identified terrorist groups such as Hezbollah raises the fear that officials, with or without approval from the top leadership, could pass a usable nuclear device to radical, undeterrable non-state groups. Alternatively, crucial technical know-how or a finished bomb could be transferred to other governments, along the lines of the former Pakistan-centered A. Q. Khan network. Even short of such leakage, the very possession of nuclear weapons by a state openly opposed to U.S. presence, allies, interests, and values would alter the balance of power within the Middle East in ways that could constrain U.S. options in future regional crises.

The second type of concern has less to do with Iran per se than the impact of an additional nuclear-capable state on the global non-proliferation regime. Especially following the "break-out" by India and Pakistan in the late 1990s, and the claimed development of weapons by North Korea, such an obvious failure of the NPT system could trigger its collapse and produce a domino effect of other countries scrambling to acquire such weapons themselves. In the absence of the technical or organizational elements for "stable deterrence," such a chain reaction would only raise the stakes and heighten tensions among regional rivals. It would also multiply the potential opportunities for unauthorized or accidental use of nuclear weapons as well as their transfer to non-state terrorist or organized crime networks.

Such issues underpin the broad consensus against a nuclear Iran. Much less unity exists, however, regarding the best means of averting such an outcome.

\section{EU Negotiations}

The first option for the U.S. would be to lend its support to the negotiations with Iran being conducted by the so-called EU "troika" of France, Germany, and Great Britain. In November 2004, these produced a signed agreement under which Iran pledged to suspend activities related to the enrichment and reprocessing of nuclear fuel during further talks on potential technical, economic, and political support from the European Union.

An advantage of this option is simply the fact that it is already on the table. Encouraging European efforts here would also provide an opportunity for the type of burden-sharing in security matters the U.S. has been calling for from its NATO partners for years. Finally, an affirmative response to expressed European requests for stronger backing could help overcome lingering tensions caused by disagreements over Iraq and reaffirm the solidity of transatlantic relations.

Most American officials, however, simply don't believe these negotiations will work. Their doubts extend to issues of duration, verification, and the basic sincerity of 
Iran. The Iranians failed to honor a similar agreement signed in October 2003, and have expressly characterized their latest commitment as "a voluntary confidencebuilding measure and not a legal obligation." Even should Iranian fealty to this version prove more robust, there is a sense that the agreement simply rewards prior misbehavior, setting a poor precedent for other aspiring nuclear powers. Worse, critics charge that the process smacks of "appeasement," with all the historical and moral baggage carried by that term. ${ }^{2}$

\section{Economic Sanctions}

A second approach for the U.S. would be to threaten or impose tougher economic sanctions on Iran unless it agreed to strict verification that it had abandoned specific types of activity that could lead to production of nuclear weapons. This would add a "stick" to the primarily "carrots" offered under the troika talks. The timing for such leverage might also be more advantageous than in the recent past if analysis is correct that Iran's leaders have embraced a "China model" strategy of seeking to defuse popular resentments of political restrictions through increased economic growth and opportunity. ${ }^{3}$

On the negative side, sanctions alone have at best a highly mixed historical record of success in changing the behavior of targeted governments. President Bush's remark to the press in December 2004 that the U.S. had already "sanctioned [itself] out of influence" with Iran reflected the fact that existing U.S. sanctions, strengthened most recently by the Helms-Burton Act, leave little room for imposing additional restrictions unilaterally.

The chances of winning support for broader international measures at this time also appear limited. The Europeans have presented their approach of negotiated incentives as a more promising alternative to sanctions. In 2004, China signed two major longterm energy agreements with Iran, each totaling tens of billions of dollars. Russian technicians are nearing completion of a nuclear power facility in Iran at Bushehr, and talks have taken place on the possible construction of several additional reactors. Finally, with world oil prices hovering at $\$ 40-50$ per barrel, effective broad-based sanctions against Iran could inadvertently spark a global energy crisis, with serious consequences for the U.S. and other petroleum-dependent economies.

\section{UN Referral}

A third possibility, and one advocated by U.S. officials, is formal referral of the Iran case to the UN Security Council for discussion as a looming threat to international peace. This step offers the prospect of increasing international focus and pressure on the matter, adding legitimacy to any other measures taken later, and countering the critique of the U.S. as reflexively unilateralist.

See the editorial “Appeasing Iran,” Wall Street Journal, 12 November 2004.

Afghin Molavi, "Buying Time in Tehran," Foreign Affairs (November/December 2004): 916. 
However, other members of the Security Council, including all four other permanent members, have opposed this step. As with economic sanctions, France and Britain have presented the troika framework to Iran as a means of avoiding direct Security Council scrutiny. China's Foreign Minister Li Zhaoxing underlined his government's opposition on a visit to Tehran last November, in keeping with Russia's longer standing position.

\section{Preemption by Regime Change}

The remaining three approaches are variants of preventive action of the type covered by the label "preemption" in the 2002 U.S. National Security Strategy. The first of these would be Iraq-style preemption via change of regime. Indeed, in the run-up to intervention in Iraq, an oft-quoted saying in Washington policy circles had it that "everyone wants to go to Baghdad; real men want to go to Tehran." Press reports in early 2005 of military updating of contingency war plans for Iran and of sightings of reconnaissance drones over that country have fueled speculation that such action is in the works.

The case for applying large-scale military preemption to Iran is if anything stronger than that for Iraq in 2002-2003. Iran's open nuclear efforts - together with its admitted past omissions in disclosure of enrichment activity - put it ahead of even the high-end pre-2003 intelligence estimates of Iraq's nuclear capacity. The same is true of Iran's missile program and record of ties to terrorist groups. Furthermore, given the prominence of debate on Iraq, President Bush's successful re-election could be interpreted as a fresh popular mandate to apply preemptive strategies elsewhere. Finally, thousands of U.S. troops are already in Iraq and Afghanistan, Iran's immediate neighbors, theoretically offering the basis for a two-pronged attack.

Negative considerations here also begin with the fact that thousands of U.S. troops are already in Iraq and Afghanistan. Maintaining approximately 150,000 troops in the region through successive rotations has already strained the U.S. military's manpower resources. The hopeful recent experience of national elections in both countries and accelerated training for indigenous security forces notwithstanding, the immediate possibilities for diverting significant forces from current assignments in these countries and/or mobilizing comparable numbers of additional U.S. forces from elsewhere are doubtful at best.

At the same time, Iran's conventional military, while ultimately no match for the U.S., would present a significantly more formidable foe that of Iraq after the 1991 Gulf War and a decade of sanctions. Among Iran's foreseeable first moves in the event of hostilities would be to stir up increased unrest inside Iraq in an effort to challenge and tie down U.S. resources. Iranian forces could also threaten oil shipping through the chokepoint of the Straits of Hormuz.

International support for U.S.-led regime change would also be lower than it was with Iraq. In that case, UN resolutions dating from the Gulf War in the early 1990s, together with Iraq's widely accepted record of repeated violations, provided a separate legal basis for intervention. With Iran, the justification would rest on prevention alone. 
Although President Bush also used the occasion of his January 2005 State of the Union address to pledge to "stand with" Iranians striving for greater freedom in their country, the perceived legitimacy of using military force as a means to that end has been further weakened by the stated opposition of Iran's best-known pro-democracy activist Shirin Ebadi, recipient of the 2003 Nobel Peace Prize. ${ }^{4}$

Accordingly, even the countries that have provided the greatest levels of support in Iraq are unlikely to do so again in Iran. British Foreign Secretary Jack Straw has called military intervention there "inconceivable" and unlikely to be justified under "any circumstances.",

\section{Preemption by Surgical Strike}

An alternative to regime change would be a more focused, limited attack aimed at destroying the facilities and infrastructure of Iran's nuclear program. This would require far fewer forces for much shorter duration. Even should such strikes also spark a popular revolt, there would be no necessary long-term responsibility for stabilization of the country. Domestic and international criticism could also be expected to be comparatively muted and short-lived.

On the other hand, many of the negatives of the regime change approach would still apply. International criticism, while reduced, could still prove significant; Foreign Secretary Straw's remarks above, for instance, actually referred to the prospects of air strikes. Rather than undermining the Iranian regime's hold on power, such strikes could bolster its popular support.

Finally there is the question of effectiveness. Along with long experience of dealing with external surveillance and international inspection regimes, the precedent of the Israeli air strike against the Iraqi nuclear reactor at Osirak in 1981 has taught Iran and other nuclear aspirants to pursue greater survivability for the core elements of their nuclear capabilities. To this end, the Iranians have dispersed facilities across the country, hardened or hidden many sites underground, and created redundancies in important areas. Moreover, successful destruction of the twenty to forty key sites cited in one estimate would significantly set back Iran's program, but would leave the country with the technical knowledge to rebuild in the future.

\section{Preemption by Proxy}

A final version of preemption would be explicit or implicit encouragement to a concerned third party to carry out surgical strikes on its own without overt U.S. involvement. The leading candidate for this role, Israel, has strong regional intelligence capabilities and, as noted above, recent experience in targeted strikes. Vice President Dick Cheney's remarks in a January 2005 radio interview suggesting that the U.S. might not be able to restrain Israel from undertaking such actions have been the highest-level ac-

4 Shirin Ebadi and Hadi Ghaemi, "The Human Rights Case Against Attacking Iran," New York Times, 8 February 2005.

5 James Blitz, "Straw Rules Out Support for War in Iran," Financial Times, 5 November 2004. 
knowledgement of this scenario. For their part, Israeli officials, including Foreign Minister Silvan Shalom, have denounced Iran's negotiations with the EU as a transparent effort simply "to buy time."

This approach would of course also entail great risks. U.S. denials of involvement would be subject to doubt, and the concerns regarding effectiveness would still apply. Even without encouragement from Iran, such action by Israel in particular would have an inflammatory impact across the Middle East, including in Iraq. It would also likely prove fatal to the Israeli-Palestinian peace process precisely at the moment of its most hopeful progress in years.

\section{Conclusion}

The not terribly profound conclusion to be drawn from this survey is that there are no good, easy options. However, two basic points will have to guide the U.S. and others in confronting this challenge.

First, any effective policy will have to combine both carrots and sticks. Given the many plausible reasons for Iran to desire nuclear weapons, it will give up its steady development of the capability to build them only when it concludes that its key security and economic interests will be advanced by doing so and harmed by not.

Second, it follows that greater public coordination and unity between the U.S. and Europe is needed. The current approach, described by former U.S. Deputy Secretary of State Richard Armitage as a "good cop, bad cop" routine, has largely run its course. Key carrots, such as security guarantees and WTO membership, require support from the U.S. Similarly, key potential sticks, such as economic sanctions, UN action, and the prospective shadow of military force, become more credible when backed by the Europeans.

The high-profile visits to Europe in February 2005 by Secretary of State Condoleezza Rice, Secretary of Defense Donald Rumsfeld, and President Bush himself sharpened the transatlantic discussion on Iran without fully closing the existing gaps between the U.S. and European positions. The search for a successful formula that incorporates the twin principles above thus promises to command the administration's security policy focus for some time longer, while the pressure for effective action continues to mount. 


\section{Bibliography}

Blitz, James. "Straw Rules Out Support for War in Iran." Financial Times (2004).

Champion, Marc, and Carla Ann Robbins. "EU Believes Iran is 5 to 6 Years from Atom Bomb." Wall Street Journal (2004).

Ebadi, Shirin, and Hadi Ghaemi. "The Human Rights Case Against Attacking Iran." New York Times (2005).

Molavi, Afghin. "Buying Time in Tehran." Foreign Affairs (2004). 